\title{
SUBSTANTIATION OF THE METHOD OF DETERMINATION THE OPEN- CAST MINE FINAL CONTOURS TAKING INTO ACCOUNT THE TRANSPORT PARAMETERS
}

\author{
(C) А.А. Адамчук ${ }^{1}$, О.О. Шустов ${ }^{1}$, В.В. Панченко ${ }^{1}$, М.М. Сливенко ${ }^{1}$ \\ ${ }^{1}$ Національний технічний університет «Дніпровська політехніка», Дніпро, Україна
}

\section{ОБГРУНТУВАННЯ МЕТОДИКИ ВСТАНОВЛЕННЯ ГРАНИЧНИХ КОНТУРІВ КАР'СРУ ІЗ УРАХУВАННЯМ ПАРАМЕТРІВ ТРАНСПОРТУ}

Purpose. Development and justification of the methodology for setting the boundary contours of the quarry and the payback period of capital investments for the development of the deposit in an open way, taking into account the parameters of transport, certainly the distance of transporting the rock mass and the production cost of 1 ton-kilometer.

Methods. The developed methodology was tested on a model of a mold-shaped deposit, built using the AutoCAD software. The model parameters were adopted close to bedding conditions of Novo-Dmytrivsk brown coal deposit. The data on geological cross-sectional area, area of mineral contacts with overburden rocks, rock and mineral volumes by stages and in horizontal layers are recorded in an Excel electronic data table, which is the base for calculation economic and mathematical model for a deposit open-cast mining. The model takes into account the volume of mining rocks, their excavation cost, production cost and transportation distance.

Results. Based on the constructed economic and mathematical model, the dependences of mining volumes, its cost and overburden coefficients for different mining stages and depending on the year of mining production operation were built. By analyzing the data obtained, a significant influence of the transport parameters on the mining cost has been established, which is not observed in the overburden coefficient dynamic figures by stages and years.

Scientific novelty. The relevancy of designing and planning of open-cast mining works by comparison of "geological" overburden coefficients with "economical" ones was simplified, the possibility and feasibility of comparison the actual and acceptable costs for deposit development was confirmed.

Practical value. The developed the calculating method for setting the boundary contours of the quarry and the payback period of capital investment allows to design and plan the open-cast mining of minerals with higher accuracy and, in the near future, allows to create on its base a software complex for automated mining design.

Key words: overburden coefficient, transport parameters, quarry boundary contours, mining production cost.

Introduction. The decision to create an industrial enterprise is made depending on the economic feasibility of its existence. In case of insufficient profit margins or too high risks, the investments for organization of production process are not allocated. In addition, industrial production, particularly, mining works, requires significant capital investment, which is payable in 3-5 years or more, depending on the size of an enterprise.

The size of a mining complex depends on the amount of the balance reserves of a deposit being developed and the rock mass that is extracted along with a mineral and is 
not commodity raw material. Their development, transportation and storage are reflected in the cost of a mineral mining and the environment state [1-3]. Therefore, the effective deposit exploitation is determined by an optimum ratio of the cost of mining overburden rock mass and cost of mining minerals.

Main part. In the mineral open-cast mining design practice, the quarry sizes, its period of operation and the deposit development efficiency depend on its limit mining depth and the parameters of the end quarry contours. Optimal parameters of the opencast mining are established by comparing actual indicators with acceptable ones.

Nowadays, the task of setting the boundary (end) contours of a quarry is solved by comparing the limit overburden coefficient with the contour, average, and / or current overburden coefficients. This measure was introduced in the middle of the XX century due to the complexity of calculations associated with establishing an economically viable depth of open-cast mining by calculating the cost of mining. At that time, the deposit open-cast mining was carried out in quarries with the depth of about $100 \mathrm{~m}$.

The introduction of these coefficients was aimed at simplifying the calculation of the limit depth of the open-cast mining. It was assumed that the overburden coefficient is the constant value. As an exception, various coefficients were adopted for the development of sediments and rocks. With this in mind, it should be emphasized that the value of the limit overburden coefficient depends on the actual production cost of the mineral extraction, the overburden rocks and the allowable cost of the mineral extraction (for example, the cost of extraction in underground way).

Acad. Rzhevsky V.V. emphasized that the rock mass transportation expenses influence the cost of extraction rocks with increasing of mining depth [4]. He noted that with the change in depth of mining operations the error in calculations of a deposit development cost makes 3-15\% and may not be taken into account. However, with the increase of the depth of a deposit open-cast mining to $500 \mathrm{~m}$ or more, the share of transportation expenses in the rock mass production increases and now makes 50-70\% [5-7].

Therefore, the assumption that the limit overburden coefficient is the constant value is erroneous and cannot be further used to establish the boundary quarry contours. And the attempts to apply correction coefficients to this value contradict the idea of introducing an overburden coefficient - simplification of the procedure for setting the boundary quarry contours.

Therefore, with increasing of accessibility and simplifying the electronic computing means, when setting the boundary position of the quarries' contours, it is more appropriate to comply with the conditions proposed by prof. Blyznyukov V.G. [8] that the actual costs for the development of a deposit for a certain period of its operation $\left(C_{a}, \mathrm{USD}\right)$ should not exceed the eligible costs $\left(C_{e}, \mathrm{USD}\right)$ :

$$
\begin{gathered}
C_{e} \geq C_{a}, \\
C_{e}=P_{C e} A_{p} T,
\end{gathered}
$$

where: $P c_{e}$-eligible production cost of 1 ton of a mineral, USD; $A_{p}$ - annual mineral productivity of a quarry, $\mathrm{t} ; T$ - deposit exploitation period, years 
The value of eligible costs should be calculated taking into account the market situation and the rate of return from the deposit development. The actual costs should take into account the cost of open-cast mining in certain career contours. Moreover, in view of the above, it is recommended that the cost of all processes except transportation be conditionally accepted as a constant value $\left(C_{d}=\right.$ const, USD), while to accept the rock mass transportation costs $\left(C_{t}, \mathrm{USD} / \mathrm{t} \cdot \mathrm{km}\right)$ as increasing value depending on mining depth.

$$
\begin{gathered}
C_{a}=C_{d}\left(V_{p}+P_{K}\right)+\sum_{i=1}^{n} C_{m} l_{i}\left(V_{p i}+P_{K i}\right), \mathrm{USD}, \\
l_{i}=f\left(H_{i}\right), \mathrm{M},
\end{gathered}
$$

where: $n$ - the number of horizons inside a quarry space; $V_{p i}, P_{K i}$-overburden rock and mineral volumes on the horizon number " $i$ ", $\mathrm{m}^{3} ; l_{i}$,- distance of transportation of rock mass from the $i$-horizon to the surface, $\mathrm{km} ; H_{i}-i$-horizon bedding depth, $\mathrm{m}$.

It is recommended to determine the position of the quarry contours in space provided the maximal deposit development efficiency. It is known that the operation of steep-sloping deep-bedding deposits uses a combined transport scheme, which requires the operation of at least one board placed in projected position. Therefore, prof. Dryzhenko A.Yu. proposed to form a non-working board at the end of the deposit for the possibility of creating permanent transport communications, achieving the lowest current volumes of overburden works and the possibility, under certain conditions, of internal dumping $[6,9,10]$.

However, the formation of a working board at the end of the deposit in projected position determines the location of the quarry contours inexhaustibly. Therefore, it is suggested to use the parameter $b_{x}$ - the distance from the upper edge of the quarry board in projected position to the point of intersection of the mineral contour line in the lying side and surface.

For the equal deposit development depth, the board design is assumed to be unchanged, regardless of its position in space. Therefore, the volume of rocks in the career contours is identical. Therefore, the greater share of a mineral in this volume, the more efficient the deposit exploitation is.

Based on the above, it can be argued that the position of the quarry projected contours in plane at its equal depth is determined by the parameter $b_{x}$, the value of which should be such that the volume of the border zone of a deposit is minimal. The marginal zone of the deposit is a part of the mineral deposit not prepared for extraction, for the disclosure of which it is necessary to disperse the side of the quarry and is above the bottom of the quarry [11].

After setting an optimal $b x$ parameter for the depths of a deposit open-cast mining with the step of $100 \mathrm{~m}$, the cost of a deposit development at these depths is calculated and compared with the eligible cost. Further calculations and comparisons are specified for depths with a step equal to the height of the ledge $(10,12,15 \mathrm{~m})$. The depth of development at which the cost of open-cast mining is close to the eligible is considered as ending.

Thus, in determining the position of the project contours of a quarry is advisable to set by optimizing the parameter $b_{x}$, and to take the depth of development taking into 
account the cost of extracting and transportation of the entire volume of rocks and compare it with the eligible cost, determined by the market conditions and rate of return.

Method description. An important issue in the design of a mining enterprise is to determine its payback period. To do this, it is necessary to build a model of open-cast mining, close to the real one by its geometric parameters. To divide the model into $j$ horizontal layers, which in turn are divided into $i$ stages of development based on the principle of interconnection of deepening of mining operations and the displacement of working ledges [12]. The vertical power of a horizontal layer should be equal to the difference of the elevation marks of adjacent horizons, and the horizontal stage power should not exceed the bottom width of the trench (when opening a new horizon) or the value of displacement of the working board to open the horizon below the current altitude.

$$
0<l_{e} \leq h_{v}\left(\operatorname{ctg} \alpha_{p}+\operatorname{ctg} \beta\right)+b, \mathrm{~m}
$$

where: $h_{v}$ - the vertical power of the horizontal layer, m; $\alpha_{p}$ - the slope angle of the working ledge, degrees; $\beta$ - the slope angle of non-working ledge, degrees; $b$-width of non-operational safety berm, $\mathrm{m}$.

Further, it is necessary to calculate the volumes of rocks (separately to determine the volume of minerals) in stages and determine in them the average distance of rock transportation to the surface. To calculate the distance of transport of the rock mass volume at the $i^{\text {th }}$ stage in the $j_{-}{ }^{\text {th }}$ horizontal layer by this formula:

$$
l_{m p . i . j}=\frac{1000 H_{j} K_{p . m . j}}{i_{j}}+\frac{1}{2} l_{i . j . e}+\sum_{1}^{i-1} l_{i . j . e}, \mathrm{~m}
$$

where: $H_{j}-$ the difference of elevation marks of the surface and the foot of the $j_{-}{ }^{\text {th }}$ horizontal layer, $\mathrm{m} ; K_{p . m . j}$-the coefficient of the route development for the vehicle operating in the $j_{-}{ }^{\text {th }}$ horizontal layer; $i_{j}$-the control slope of the vehicle route, operating in the $j_{-}{ }^{\text {th }}$ horizontal layer, $\% ; l_{i . j . e}$-horizontal power of the $i_{-}{ }^{\text {th }}$ stage in the $j_{-}{ }^{\text {th }}$ horizontal layer, $\mathrm{m}$.

The cost of mining in the stage is calculated by these formulas:

$$
\begin{gathered}
C_{V_{p i . j . j}}=V_{p . i . j}\left(C_{m} l_{m p . i . j}+C_{\partial}\right), \\
C_{P_{K, i . j}}=P_{K . i . j}\left(C_{m} l_{m p . i . j}+C_{\partial}\right), \\
C_{K K . i . j}=\frac{C_{V_{p . i . j}}+C_{P_{K . i . j}}}{P_{K . i . j}},
\end{gathered}
$$

де: $C_{V_{p, i . j}}$-the cost of overburden rocks at the $i_{-}{ }^{\text {th }}$ stage in the $j^{-}$th horizontal layer USD; $V_{p . i . j}$-the volume of the overburden rocks at the $i_{-}{ }^{\text {th }}$ stage in the $j^{- \text {th }}$ horizontal layer, $\mathrm{m}^{3} ; C_{P_{K, i, j}}$-the cost of mining at the $i_{-}{ }^{\text {th }}$ stage in the $j_{-}{ }^{\text {th }}$ horizontal layer USD; $P_{K . i . j}-$ the amount of mineral at the $i_{-}{ }^{\text {th }}$ stage in the $j_{-}{ }^{\text {th }}$ horizontal layer, $\mathrm{t}$; $C_{K K . i . j}-\operatorname{cost}$ of extraction of 1 ton of mineral at the $i^{\text {th }}$ stage in the $j_{-}{ }^{\text {th }}$ horizontal layer, USD/t. 
The stage duration is then calculated taking into account the accepted annual productivity of a mineral mining quarry and overburden equipment capacity during commissioning of a quarry. Then we get the dynamics of mining productivity and its cost. We determine the amount of capital investment and, taking into account the received charts and the cost of selling the mineral, we calculate the payback period of the investments.

The nature of the influence of transport parameters will be considered on the example of the model of development of a typical mold-like deposit of brown coal in Western Donbass (Fig. 1). In the first and second horizontal layers, the work of a rotary excavator in combination with a belt conveyor is assumed, in the following sequence a cyclic excavator in combination with motor transport [13].

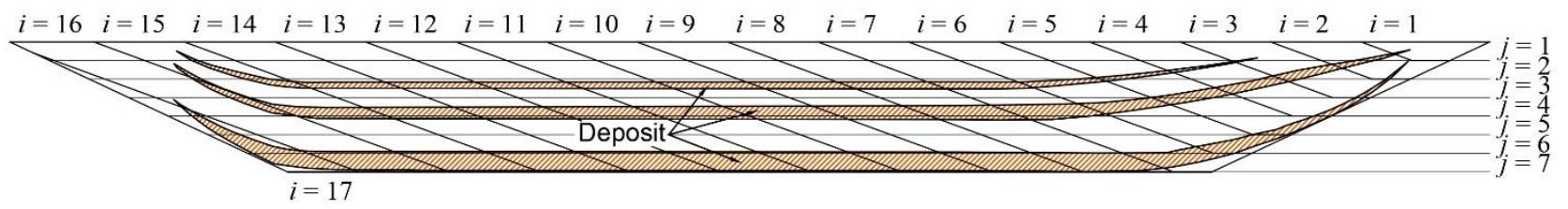

Fig. 1. The model of development of moldy-like deposit, divided into horizontal layers $(j=7)$ and stages $(i=17)$

The amount of mining works in each of the horizontal layers and stages of a deposit development is calculated, and according to formulas (5-9) its cost is calculated in the stage of a deposit development (Fig. 2-5).

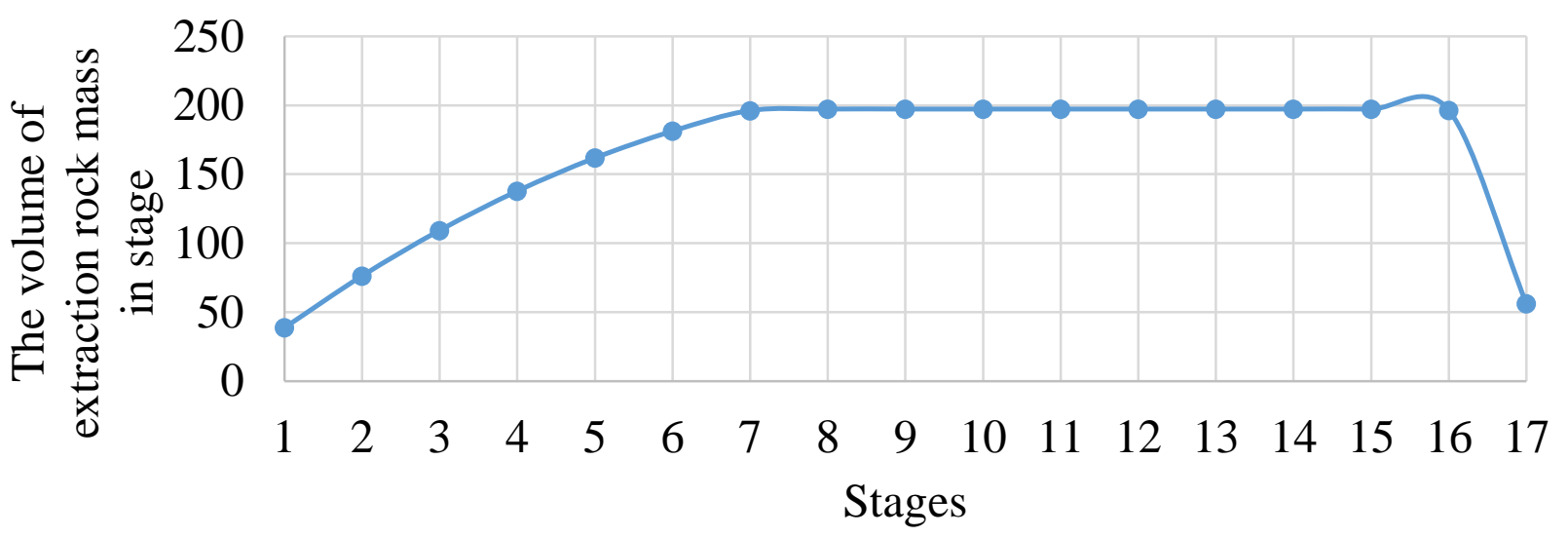

Fig. 2. Mining works distribution by stages

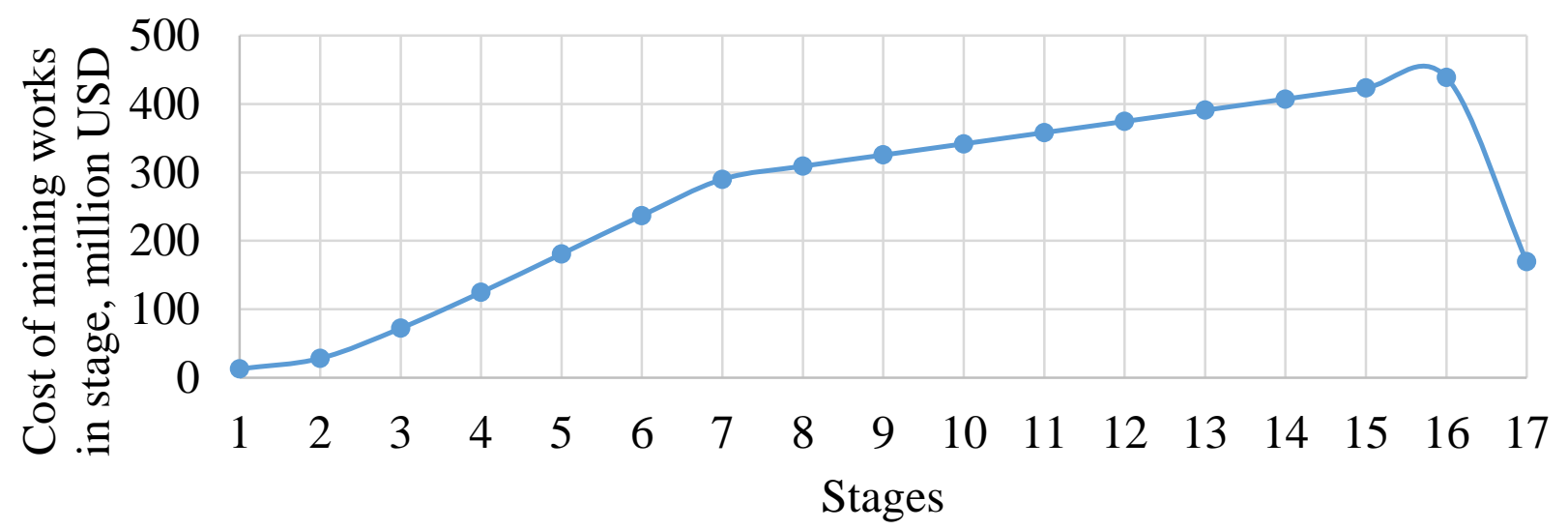

Fig. 3. Cost of mining stages 
Figures 2 and 3 show the volume of mining works in stages and the cost of their deposit developing, respectively. Both charts show their growth from the first to the seventh stage. This is due to the deepening of mining operations and, consequently, the increase in the amount of diversity of the working board with the opening of deep quarry horizons. However, the volume of mining is increasing by $407.9 \%$ and their value cost by $2144 \%$.

Further, the stages from the seventh to the sixteenth have the same volume of mining works, while their cost increases by $51.4 \%$. At the seventeenth stage, mining operations are completed, the volume of which is $45 \%$ larger than at the opening of the deposit at the first stage of the development. While the cost of mining works in the seventeenth stage is $1213 \%$ higher than in the first one. In comparison with the first stage, the volume of mining works is increasing by $407.9 \%$ and its cost by $3297.6 \%$.

Figure 4 shows the phased distribution of minerals in an open-cast mining model. The mineral mining volume increases by 19.6 times from the second to the eighth stage, it is associated with opening the deep quarry horizons and the output to the maximum deposit capacity. From the eighth to the fifteenth stage, the volume of minerals is almost unchanged, due to the horizontal deposit bedding in this part of the rock array. While their number decreases at the sixteenth and seventeenth stages due to fading out of mining operations.

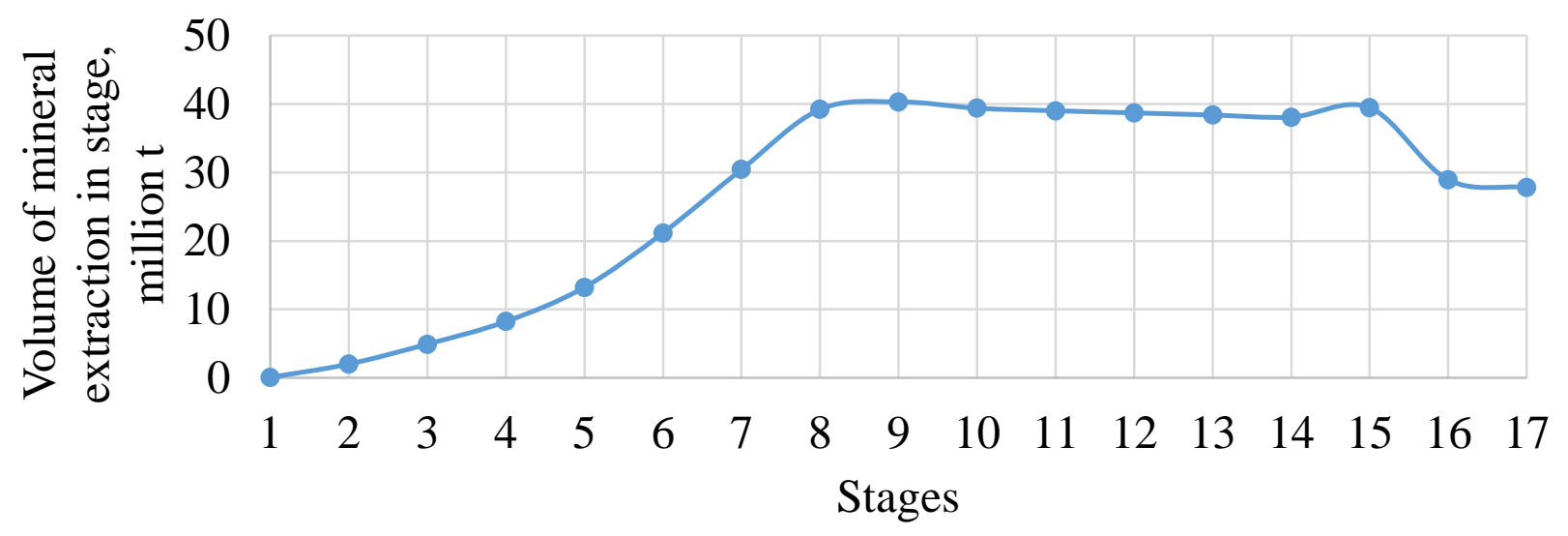

Fig. 4. Mineral volume distribution by stages

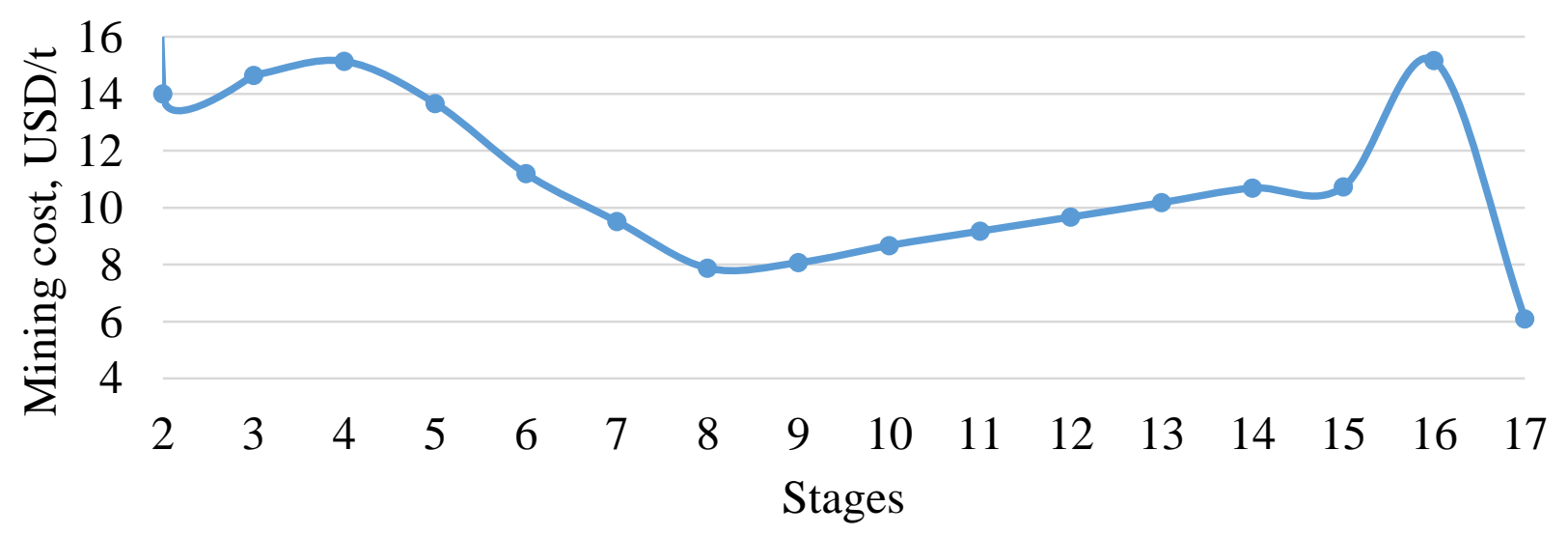

Fig. 5. Cost of mining 1 ton of mineral in stage 


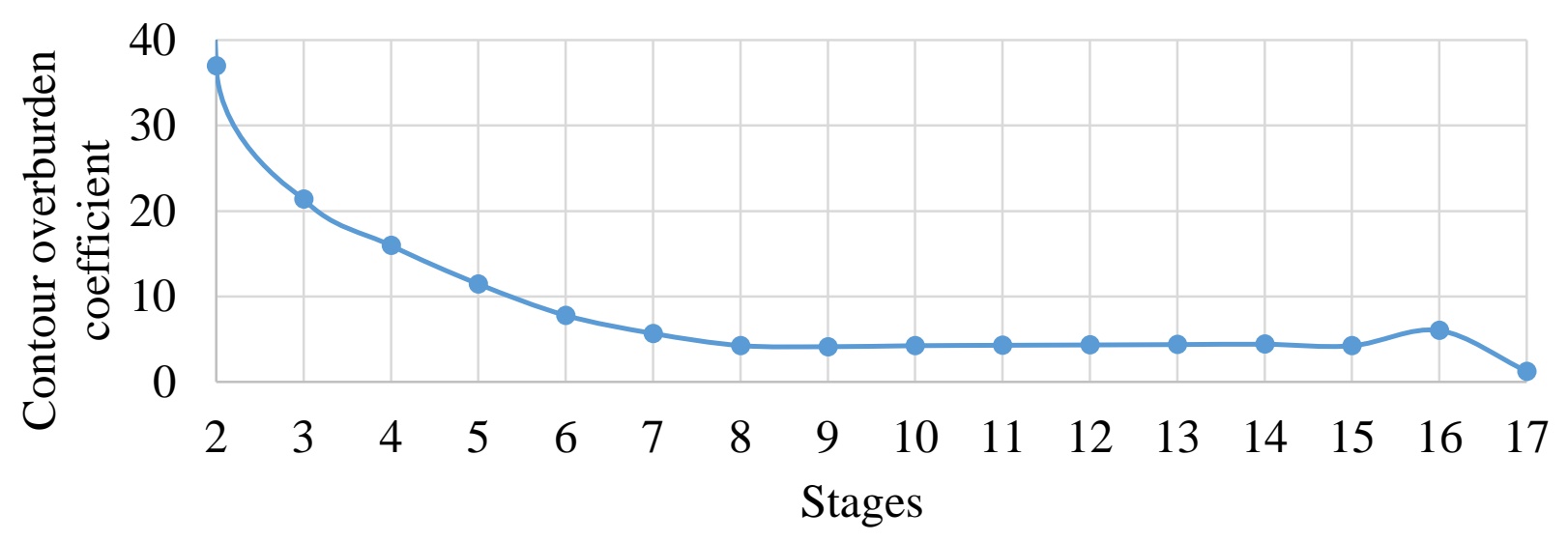

Fig. 6. Contour overburden coefficient at the deposit development stage

Figures 5 and 6 show the dynamics of change according to the cost of extraction of 1 ton of mineral resources and contour overburden coefficient. The first stage is not shown in charts, as the mining works are associated mainly with removal of overburden rocks. The contour overburden coefficient from the second to the eighth stage decreases by $767.8 \%$ as the volume of the overburden works increases by $158.8 \%$ and extraction works - by $1860 \%$. Further, at steps $8-15$, the overburden coefficient is almost unchanged 4.2-4.4, on the sixteenth stage it increases to 6 and at the completion of the mining operations it drops to 1.2.

However, the cost at the stages 2-4 and 8-15 increases, unlike the overburden coefficient, due to an increase in the cost of transporting the rock mass by increasing the distance of its transportation from the bottom to the surface. Thus, it is obvious that for the considered conditions of the deposit, on the example of the constructed model, the value of the contour overburden coefficient cannot be fully taken into account when designing a quarry and justifying its boundary contours.

The projected capacity of the mining quarry is 9 million tons / year. Then, in the deposit development, taking into account the need to prepare the pioneer mining front, the required productivity will be reached in the fourth year of mining operations (Fig. 7). Taking into account the data of the Figure 4, we determine the duration of each stage and calculate the productivity of the quarry with extraction rock mass (Fig. 8) and its annual cost (Fig. 9).

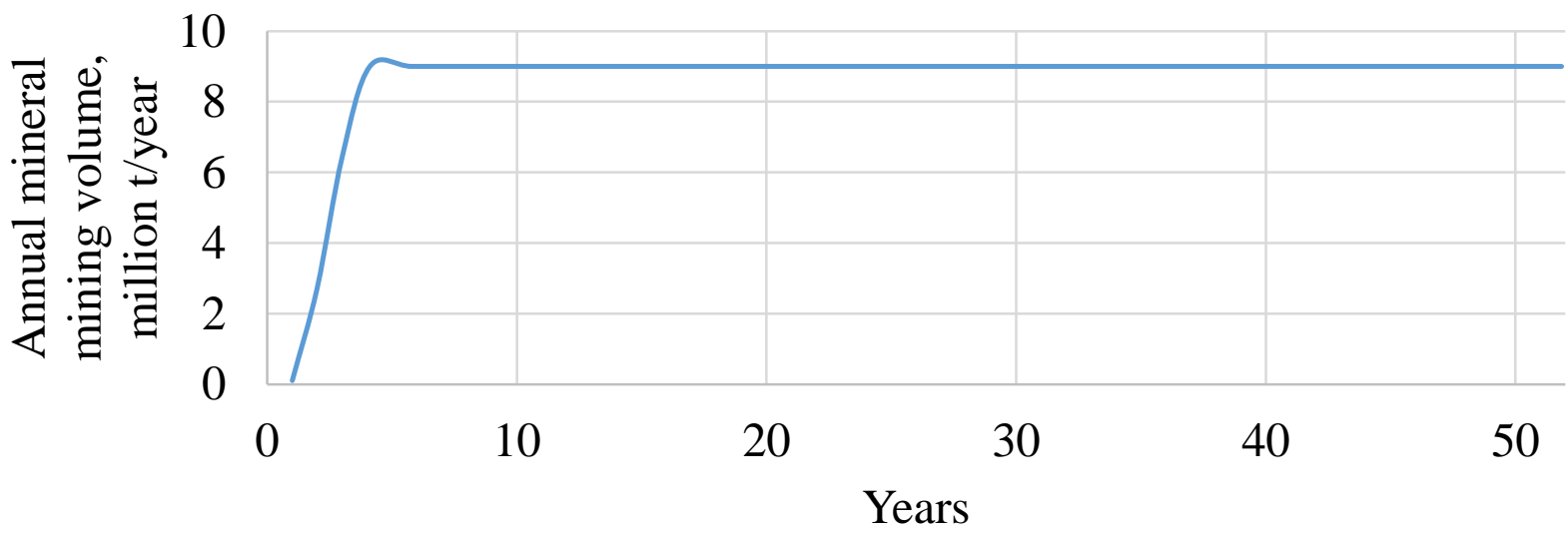

Fig. 7. Mineral mining quarry productivity for years 


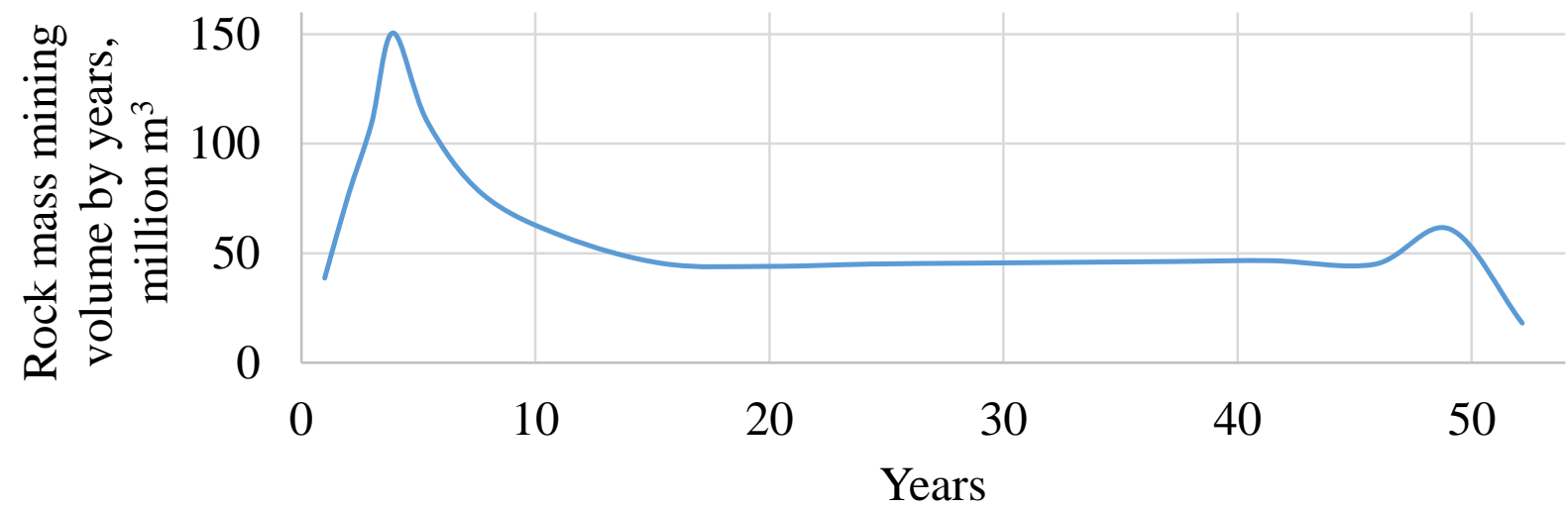

Fig. 8. Rock mass extraction quarry productivity for years

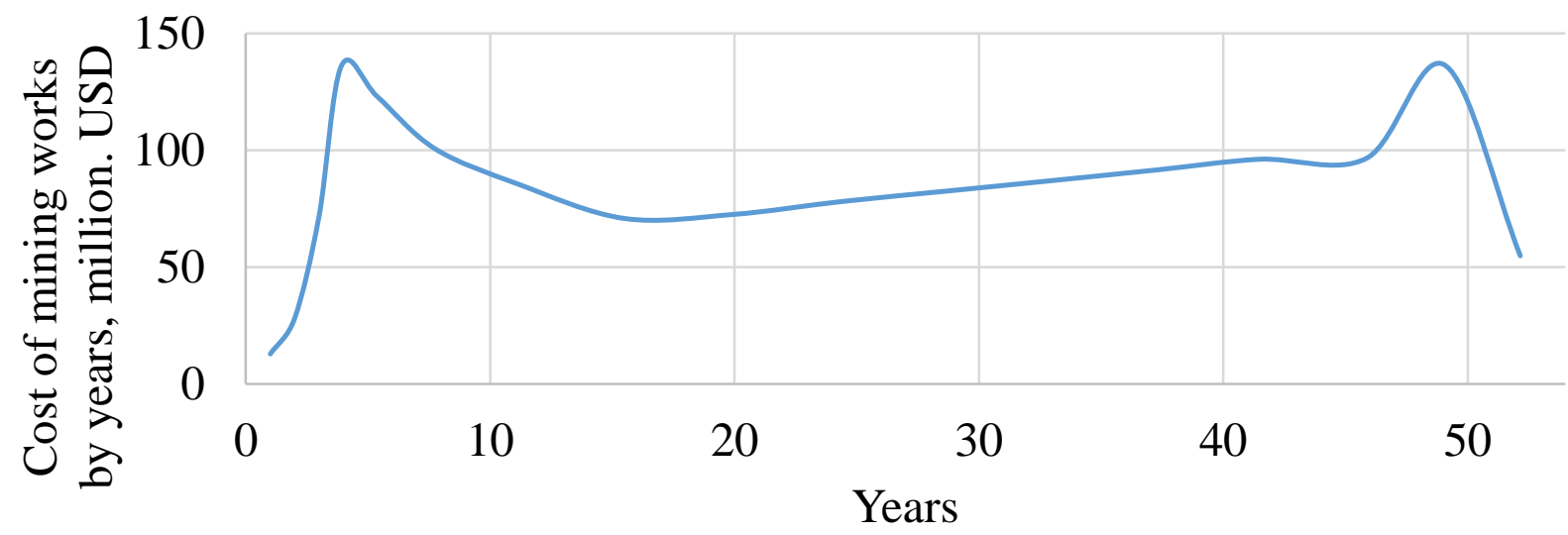

Fig. 9. Dynamics of mining work cost change for years

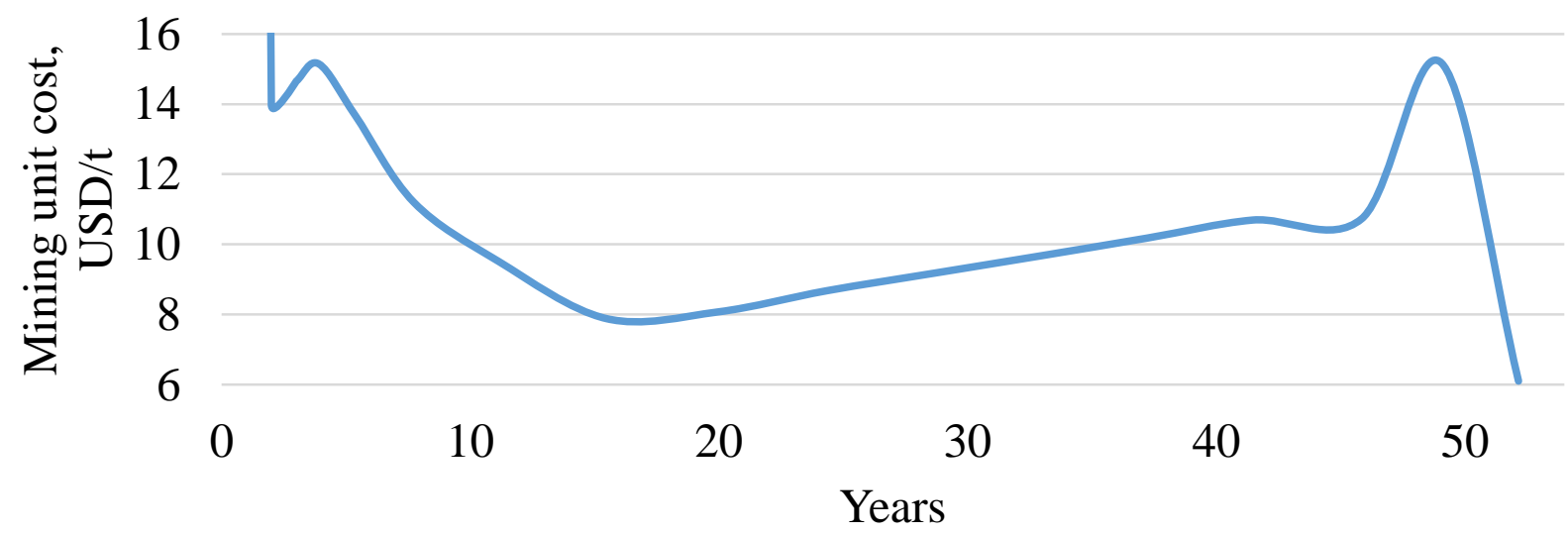

Fig. 10. Dynamics of unit cost change for 1 ton of minerals 


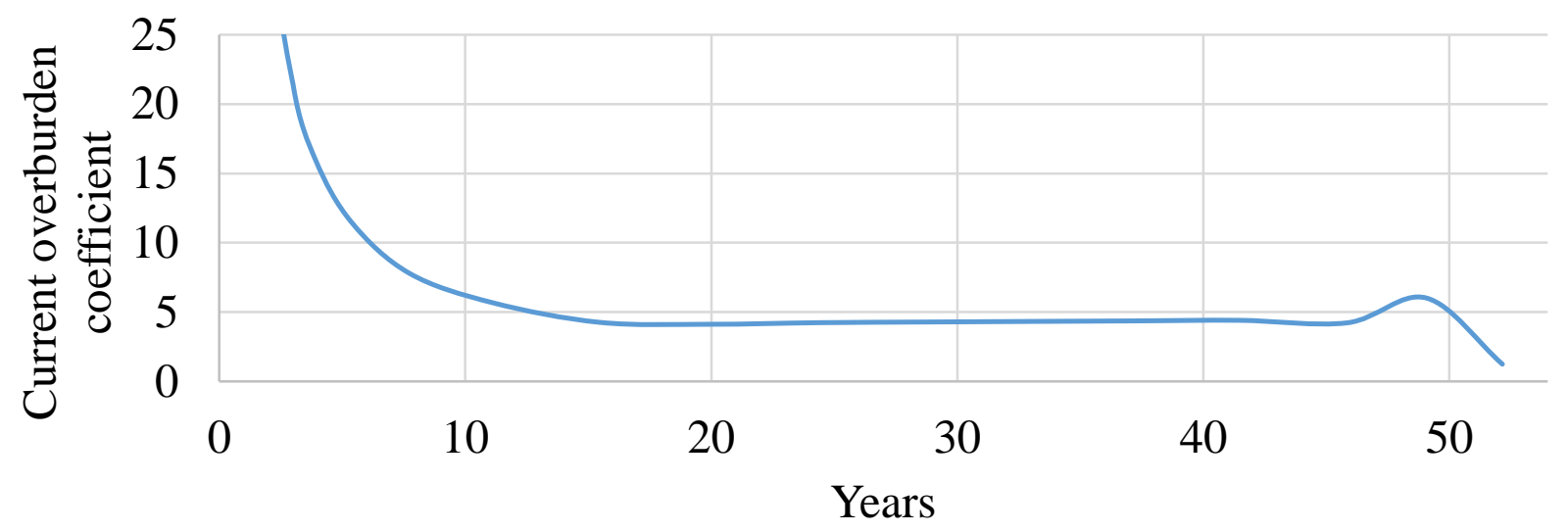

Fig. 11. Dynamics of the current overburden coefficient change for years

The dynamics of decrease and increase in the unit mining cost (Fig. 10) and the current overburden coefficient (Fig. 11) are similar to those shown in the Figures 5 and 6 , respectively. It should be noted that the current overburden coefficient has been taken into account as planned one for calculation of the unit mineral mining cost for a certain period of the deposit development. However, based on the above, for the conditions of development of a typical moldy-like deposit, it is inappropriate to consider the current overburden coefficient during planning its development.

The payback period for capital investments for industrial production is calculated by this formula:

$$
T_{p b}=C I / P,
$$

де: $C I$ - capital costs (investments) for creation an object, USD; $P$ - profit gained from selling finished products, USD/year.

The profit is determined by this formula:

$$
P=I_{s}-C_{p}, \mathrm{USD} / \text { year, }
$$

where $I_{s}$ - income from the finished products sales, USD/year. $C_{p}-$ cost of production, USD/year.



Fig. 12. Cumulative chart of the profit accumulation function for calculation pay-back period of capital investments 
Since the specifics of a mining enterprise lies in the variability of production volumes and production costs, the payback period for capital construction for a quarry should be calculated by comparing the cumulative function of the accumulation of profit from selling each mineral with the value of capital costs (Fig. 12).

Figure 12 shows that the first year the company operates with loss, during its construction period, the next 6 years it covers it capital costs. Thus, if the conditional cost of the mineral sale is $30 \mathrm{USD} / \mathrm{t}$ and capital expenditures of 680.7 million USD [13], their payback period will be 7 years, after which the company will give 133.5-215.1 million USD depending on the deposit bedding conditions and the distance of transportation of the rock mass.

Conclusions. The efficiency of the proposed methodology for design and planning of open-cast mining for the development of moldy-like deposits has been proved. In addition, the analysis of the nature of the impact of transport parameters on the cost of mineral extraction allows to confirm the justice of the proposed methodology for conditions of open deposit development of other bedding conditions.

It is obviously, the application of the developed methodology involves much more effort than the comparison of the coefficients of overlap. However, the availability of the modern computing equipment eliminates labor costs and provides high accuracy of calculations.

As a mining enterprise is a complex system consisting of a large number of processes which parameters and cost change, the improvement of its economic efficiency calculating method should be aimed at taking into account more processes and the nature of their change over time. This will allow in the near future to create an effective system for automatic design and planning of open-cast mining works.

\section{References}

1. Адамчук, А.А. \& Шустов, О.О. (2018) Системний підхід до вибору нових засобів транспорту для роботи на глибоких кар'єрах. Збірник наукових пращь Національного гірничого університету, 54, 8-18.

2. Malashkevych, D., Sotskov V., Medyanyk V. \& Prykhodchenko D. (2018). Integrated Evaluation of the Worked-Out Area Partial Backfill Effect of Stress-Strain State of Coal-Bearing Rock Mass. Solid State Phenomena, (277), 213-220. doi:10.4028/www.scientific.net/ssp.277.213

3. Медяник, В. Ю. (2005). Обоснование параметров способа охраны подготовительных выработок при комбинированной системе разработки пологих пластов на больших глубинах. Днепропетровск: НГУ.

4. Ржевский, В.В. (1956). Проектирование контуров карьеров. Москва: Металлургиздат.

5. Смирнов. В.П., \& Лель Ю.И. (2002). Теория карьерного большегрузного автотранспорта. Екатеринбург: Уро РАН.

6. Дриженко, А.Ю. (2011). Карьерные технологические горнотранспортные системыл: монография. Днепропетровск: ГВУЗ «НГУ».

7. Короленко, М.К., Перегудов, В.В., Федин, К.А., Романенко, А.В., \& Протасов, В.П. (2012). Совершенствование транспортных схем выдачи руды для условий ОАО «Южный ГОК». Кривой Рог: «Дионис»

8. Близнюков, В.Г. (1978) Определение главных параметров карьера с учетом качества руды. Москва: Недра. 
9. Дриженко А.Ю., Шустов, А.А., Адамчук, А.А., \& Никифорова, Н.А. (2017). Совершенствование технологии открытой разработки железорудных карьеров Украины при их углубке. 3б. наук праџь НГУ, 52. 79-86.

10. Дриженко, А.Ю., Адамчук, А.А., Тамуя, С.А., \& Тельнов, В.Г. (2018) Дослідження параметрів внутрішніх відвалів у виробленому просторі відпрацьованих глибоких кар'єрів. Збірник наукових праць Національного гірничого університету, 53, 56-65.

11. Адамчук, А.А., Шустов, О.О., Шустова, А.О., \& Тертишний, В.А. (2019). Дослідження параметрів розвитку робочої зони при доробиі глибоких крутоспадних родовищ. Збірник наукових праць НГУ, 57, 8-18.

doi:10.33271/crpnmu/57.008

12. Собко, Б.Е., Панченко, В.В., \& Винивитин, Д.В. (2018) Обоснование технологических принципов оперативного планирования открытых горных работ. Збірник наукових пращь Національного гірничого університету, 54, 107-117.

13. Дриженко, А.Ю., Бондаренко, А.О., Анісімов, О.О., Нікіфорова Н.А., Шустов, О.О., Чернорай, А.М., Бєлов, О.П., Токар, Л.О., Адамчук, А.А., Черняєва, О.В., \& Носенко, Л.А. (2016) Комплексне використання бурого вугілля та супутніх порід при відкритій розробичі родовищ Украйни над сольовими штоками. Eтап. Встановлення закономірностей розподілу бурого вугілля та супутніх корисних копалин в умовах родовищ над сольовими штоками (проміжний звіт ГП-483). Національний гірничий університет

\begin{abstract}
АНОТАЦІЯ
Мета. Розроблення і обгрунтування методики встановлення граничних контурів кар'єра і терміну окупності капітальних інвестицій на розроблення родовища відкритим способом із урахуванням параметрів транспорту, а саме відстані транспортування гірничої маси і собівартості 1 тонно-кілометру.

Методика. Розроблена методика апробована на моделі родовища мульдоподібної форми, побудованої із застосуванням програмного забезпечення AutoCAD. Параметри моделі прийняті наближеними до умов залягання Ново-Дмитрівського родовища бурого вугілля. Дані про площі геологічного перерізу, площі контактів корисної копалини із породами розкриву та об'єми гірських порід і корисних копалин за етапами і в горизонтальних шарах занесені в електронну таблицю Excel, на базі якої побудована економіко-математична модель розроблення родовища відкритим способом. В моделі враховані об'єми видобування порід, їх вартість екскавації, собівартість та відстань транспортування.
\end{abstract}

Результати. На базі побудованої економіко-математичної моделі побудовані залежності об'ємів видобування, його вартості та коефіцієнтів розкриву для різних етапів розробки та в залежності від року існування гірничовидобувного виробництва. Шляхом аналізу отриманих даних, встановлено значний вплив параметрів транспорту на вартість гірничих робіт, який на графіках динаміки коефіцієнтів розкриву в етапах та за роками не спостерігається.

Наукова новизна. Спростована актуальність проектування та планування відкритих гірничих робіт шляхом порівняння «геологічних» коефіцієнтів розкриву із «економічними», підтверджена можливість і доцільність порівняння фактичних і припустимих витрат на розроблення родовища.

Практична значимість. Розроблена методика розрахунку встановлення граничних контурів кар'єра і терміну окупності капітальних інвестицій дозволяє вести проектування і планування відкритої розробки родовищ корисних копалин з більш високою точністю i, в найближчу перспективу, дозволяє створити на іï базі програмний комплекс автоматизованого проектування гірничих робіт. 
Ключові слова: коефіцієнт розкриву, параметри транспорту, граничні контури кар'єру, собівартість гірничих робіт.

\section{АННОТАЦИЯ}

Цель. Разработка и обоснование методики установления предельных контуров карьера и срока окупаемости капитальных инвестиций на разработку месторождения открытым способом с учетом параметров транспорта, а именно расстояния транспортировки горной массы и себестоимости 1 тонно-километра.

Методика. Разработанная методика апробирована на модели месторождения мульдообразного формы, построенной с применением программного обеспечения AutoCAD. Параметры модели приняты приближенными к условиям залегания Ново-Дмитриевского месторождения бурого угля. Данные о площади геологического сечения, площади контактов полезного ископаемого с породами вскрыши и объемы горных пород и полезных ископаемых по этапам и в горизонтальных слоях занесены в электронную таблицу Excel, на базе которой построена экономико-математическая модель разработки месторождения открытым способом. В модели учтены объемы добычи пород, их стоимость экскавации, себестоимость и расстояние транспортировки.

Результаты. На основании построенной экономико-математической модели получены зависимости объемов добычи, её стоимости и коэффициентов вскрыши для различных этапов разработки и в зависимости от года существования горнодобывающего производства. Путем анализа полученных данных установлено значительное влияние параметров транспорта на стоимость горных работ, которое на графиках динамики коэффициентов вскрыши в этапах и по годам не наблюдается.

Научная новизна. Опровергнута актуальность проектирования и планирования открытых горных работ путем сравнения «геологических» коэффициентов вскрыши с «экономическими», подтверждена возможность и целесообразность сравнения фактических и допустимых расходов на разработку месторождения.

Практическая значимость. Разработаная методика расчета установления предельных контуров карьера и срока окупаемости капитальных инвестиций позволяет вести проектирование и планирование открытой разработки месторождений полезных ископаемых с более высокой точностью и в ближайшей перспективе, позволяет создать на ее базе программный комплекс автоматизированного проектирования горных работ.

Ключевые слова: коэффициент вскрыши, параметры транспорта, предельные контуры карьера, себестоимость горных работ. 